\title{
Genetic Algorithm-based Curriculum Sequencing Model For Personalised E-Learning System
}

\author{
Oluwatoyin C. Agbonifo \\ Department of Computer Science, Federal University of Technology, Akure, Ondo State, Nigeria \\ Email: ocagbonifo@futa.edu.ng \\ Olanrewaju A. Obolo \\ Department of Computer Science, Federal University of Technology, Akure, Ondo State, Nigeria \\ Email: oalarry@yahoo.com
}

Received: 20 September 2017; Accepted: 20 March 2018; Published: 08 May 2018

\begin{abstract}
Personalised learning is a way of organising the learning content and to be accessed by the individual learner in a manner that is suitable to learner's requirements. There are existing related works on personalised e-learning systems that focused on learner's preference without considering the difficulty level and the relationship degree that exists between various course concepts. Hence, these affect the learning ability and the overall performance of learners. This research paper presents a genetic algorithm-based curriculum sequencing model in a personalised e-learning environment. It helps learners to identify the difficulty level of each of the curriculum or course concepts and the relationship degree that exists between the course concepts in order to provide an optimal personalised learning pattern to learners based on curriculum sequencing to improve the learning performance of the learners. The result of the implementation showed that the genetic algorithm is suitable to generate the optimal learning path using the values of difficulty level and relationship degree of course concepts. Furthermore, the system classified the learners into three different understanding levels of the course concepts such as partially, moderately and highly successful.
\end{abstract}

Index Terms - Curriculum sequencing, genetic algorithm, personalised e-learning, course concepts, difficulty level.

\section{INTRODUCTION}

Learning is the act of acquiring new, or modifying and reinforcing, existing knowledge, behaviours, skills, values, or preferences and may involve synthesising different types of information. The ability to learn is possessed by humans, animals and some machines. Effective learning is achieved where learners take an active role in their own learning [1]. E-learning is defined as the intentional use of networked information and communications technology in teaching and learning [2]. E-learning emerges to substitute classroom face-to-face interaction with discussion boards, synchronous chat, electronic bulletin boards blogs, wiki and e-mails [3].
Personalisation refers to instruction that is paced to learning needs, tailored to learning preferences and tailored to the specific interests of different learners. In an environment that is fully personalised, the learning objectives and content as well as the method and pace may all vary [4]. Personalisation is the process of making a generalised content specific to the needs and traits of the user. Personalisation increases the effectiveness of web based applications [5]. Curriculum sequencing is an important issue to achieve learning goal especially in elearning systems.

Curriculum sequencing is an important research area for e-learning because no particular learning part is appropriate for all learners [6]. Curriculum sequencing aims at providing an optimal learning path to individual learners since every learner has different prior background knowledge, preferences, and often various learning goals [7]. Generally, inappropriate course concepts lead to learner's disorientation during learning processes, thus reducing learning performance [7]. Curriculum sequencing is another medium in managing learning routes for students to achieve curriculum goals.

Some existing works on personalised e-learning systems focused on learner's preference without considering the difficulty level of the course concepts, degree of relationship that exists between the various course concepts, and the time spent by students to learn a given course concept. Hence, the learning ability and the overall performance of learners are mostly impaired. This research paper develops a genetic algorithm-based curriculum sequencing model in a personalised e-learning system. It takes into consideration the relationship degree that exists between the course concepts and the difficulty level of each of the course concepts in order to improve the learners 'ability in online learning processes.

The rest of the paper is organised as follows: in section 2 , some related works are stated. Section 3 describes the methods of achieving the underlined objectives of the research. Section 4 discusses the results of the findings of the research work. Finally, section 5 presents a conclusion of the paper. 


\section{RELATED WORKS}

Learning theories are conceptual frameworks describing how information is absorbed, processed and retained during learning. Learning style refers to the way people learn, it is the way in which individuals begin to concentrate on, process, internalise, and retain new and difficult information [8]. In Huang et al. [9], a personalised e-learning system based on genetic algorithm and case-based reasoning approach was proposed. The research claimed that most personalised systems consider learner preferences, interests and browsing behaviours when providing personalised curriculum sequencing services, the system usually did not consider whether learner ability and the difficulty level of the recommended curriculums are matched to each other.

In Oduwobi [10], a personalised electronic learning material recommender system was developed. The research stated that the traditional learning approach is based on general recommendations in which the same learning item(s) is recommended for an entire group of learners. However, the research work was based on user's profile and on the highest rated items by learners which are not enough bases for a fully personalised system.

Muthulakshmi and Uma [11] designed an ontologybased e-learning system for sports domain. E-learning has been used widely in web technology aided learning process, video conferencing etc. E-learning provides effective services online than any other computer aided tutor available. However, this research do not query template that will be useful for data extraction.

Agbonifo et al. [12] developed a new learning model that deployed fuzzy c-means clustering technique using Honey and Mumford learning style dimensions to identify and classify learner learning preference and match learner with appropriate content presentation that meet his/her requirements. Also, new assessment parameter modalities were built into the model. Neurofuzzy expert reasoning technique was used to evaluate learner learning capability relative to the learning concepts processes obtained and stored in the learner profile during the interaction of the learners with the system. However, the research did not consider the difficulty level of the course concepts.

Elusoji [13] developed adaptive personalised elearning based on Felder Silverman Learning Style Model where learning contents are sequenced using the knowledge tree technique. Furthermore, the learners' knowledge which focused on learners' interest on visited learning objects with respect to learner's educational preference throughout the online learning process. Kmeans clustering was used to divide the learning preferences into eight groups and correspondence analysis is used to partition the learning preferences into four dimensions to assign learners with common preference and interests to the same group. The research did not consider the curriculum difficulty level and concepts relationship.

\section{SYSTEM DESIGN}

This section discusses the system architecture, mathematical modeling and system flowchart.

\section{A. System Architecture}

The architecture of the proposed personalised elearning system is depicted in Fig 1. It consists of various components which interact together to present personalised course concepts to meet the learning ability of the individual learners. The interface agent provides a friendly interactive medium for interacting with the users and it serves as an information channel for communicating with the system. It provides the functions of account management, authorisation and query searching. The user account database stores the profile of the users, such as the names, sex, age, unique identification numbers (authorisation and verification) and status.

The testing items database contains the pretest questions based on the course concepts. The learning course concepts are the various topics in a course with detailed note on each of the topics that the individual learners are expected to study very well during the learning process. The responses of learners to the questions are used to obtain course concept difficulty and the degree of relationship between the various course concepts.

\section{B. Genetic Algorithm-Based Curriculum Sequencing Model}

The proposed model is made up of two major parameters; the concept relationship degree and concept difficultyl level. Pasquale et al. [14] and John and Joseph [15] models are adapted to establish the degree of relationship between two course concepts. Each course concept is represented as vectors in a multidimensional Euclidean space. The generic element $\mathrm{w}_{\mathrm{i}, \mathrm{k}}$ in the space can be defined as:

$$
w_{i, k}=t f_{i, k} \times \log \frac{N}{d f_{k}}=t f_{i, k} \times I D F
$$

Iwhere $\mathrm{w}_{\mathrm{i}, \mathrm{k}}$ represents the importance/weight of the $\mathrm{k}^{\text {th }}$ term in the $i^{\text {th }}$ concept, $\mathrm{tf}_{\mathrm{i}, \mathrm{k}}$ is term frequency of the $\mathrm{k}^{\text {th }}$ term, which appears in the $\mathrm{i}^{\text {th }}$ concept, $\mathrm{N}$ denotes the total number of concepts in the database, $\mathrm{df}_{\mathrm{k}}$ is the document frequency of the $\mathrm{k}^{\text {th }}$ term (the number of concepts containing term $\mathrm{k}$ ). The logarithm is called the inverse document frequency (IDF). Assume that there are $m$ total terms under union of all linguistic terms of the $i^{\text {th }}$ concept and jth concept. The concept relation degree for the $i^{\text {th }}$ and $\mathrm{j}^{\text {th }}$ concept can be calculated using the cosinemeasure as defined in (2): 


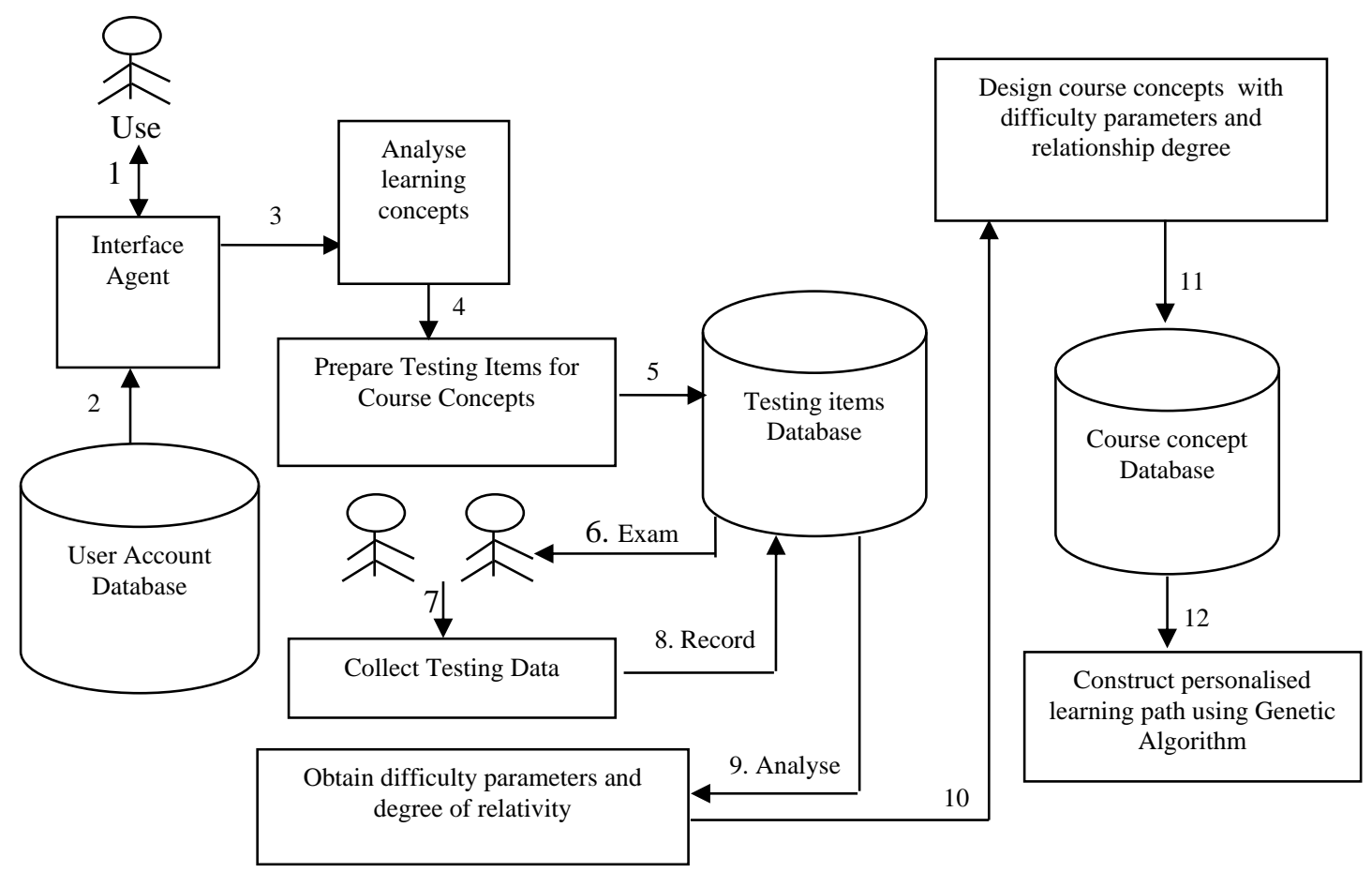

Fig.1. Architecture of the Personalised E-learning System.

$$
r_{i, j}=\frac{\sum_{h=1}^{m}\left(w_{i, h}\right)\left(w_{j, h}\right)}{\sqrt{\sum_{h=1}^{m}\left(w_{i, h}^{2}\right)\left(w_{j, h}^{2}\right)}}
$$

where Concept $\mathrm{i}\left(\mathrm{C}_{\mathrm{i}}\right)$, and Concept $\mathrm{j}\left(\mathrm{C}_{\mathrm{j}}\right)$ are expressed as follows: $C_{i}=\left\{w_{i, 1}, w_{i, 2}, \ldots, w_{i, m}\right\}$ and $C_{j}=\left\{w_{j, 1}, w_{j, 2}, \ldots\right.$, $\left.\mathrm{w}_{\mathrm{j}, \mathrm{m}}\right\}$, respectively, represent the vectors in a multidimensional space for the $i^{\text {th }}$ and $j^{\text {th }}$ concepts, $r_{i, j}$ denotes the concept relation degree between the $\mathrm{i}^{\text {th }}$ and $\mathrm{j}^{\text {th }}$ concepts.

Assume that there are $\mathrm{n}$ total course concepts in the course concepts database, the course concepts relation matrix for all course concepts can be expressed by the matrix $\mathbf{R}$, as defined in (3):

$$
R=\frac{C_{1}}{C_{2}} \quad\left[\begin{array}{cccc}
C_{1} & C_{2} & \cdots & C_{n} \\
r_{1,1} & r_{1,2} & \cdots & r_{1, n} \\
r_{2,1} & r_{2,2} & \cdots & r_{2, n} \\
\vdots & \vdots & \vdots & \vdots \\
r_{n, 1} & r_{n, 2} & \cdots & r_{n, n}
\end{array}\right]
$$

The following describes the procedure for determining the difficulty parameters of course concepts. This research work uses a 5-point likert scale where 2 indicates "Strongly Agree", 1 is "Agree", 0 is "Undecided", -1 is "Disagree" and -2 is "Strongly Disagree". The final difficulty parameter of concepts is a linear combination of the concept difficulty parameter as defined by experts and assessed by learners, with a different weight assigned to each. By adapting Lee et al. [16] model, three definitions related to the collaborative response approach by experts and learners are described below:

Assume that the difficulty parameters of course concepts, $\left.D_{i}=\left(D_{1}, D_{2}, \ldots D_{n}\right)\right\}$ is a set of course concept difficulty parameters which includes five different difficulty parameters. $D_{1}$ represents Strongly Agree, quantified as $2, \mathrm{D}_{2}$ represents Agree, quantified as $1 ; \mathrm{D}_{3}$ represents Undecided, quantified as $0 ; \mathrm{D}_{4}$ represents Disagree, quantified as -1 , and $\mathrm{D}_{5}$ represents Strongly Disagree, quantified as -2 . Average difficulty of the $j^{\text {th }}$ concept based on experts and learners collaborative responses is as defined in (4):

$$
b_{j}(\operatorname{resp})=\sum_{i=1}^{5} \frac{n_{i, j}}{N_{j}} D_{i}
$$

where $b_{j}$ (resp) denotes the average difficulty parameter of the $\mathrm{j}^{\text {th }}$ course concept after experts and learners have given collaborative responses independently, $n_{i, j}$ represents the number of experts and learners that gave feedback responses belonging to the $i^{\text {th }}$ difficulty parameter for the $\mathrm{j}^{\text {th }}$ course concept, and $\mathrm{N}_{\mathrm{j}}$ is the total number of experts and learners that rated the $\mathrm{j}^{\text {th }}$ course concept. The final difficulty parameter of course concept is as defined in (5):

$$
b_{j}(\text { final })=w b_{j}(\text { initial })+(1-w) b_{j}(\text { response })
$$

where $b_{j}$ (final) is the final difficulty parameter of the $j^{\text {th }}$ course concept based on $b_{j}$ (initial), adjustable weight, experts and learners collaborative responses. $b_{j}$ (initial) is the initial difficulty parameter of the $\mathrm{j}^{\text {th }}$ course concept given by course experts, and $\mathrm{w}$ is an adjustable weight. Using equation $5, b_{j}$ final is used to obtain the difficulty parameter of course concept in the course concept database based on the linear combination of the course difficulty parameters as determined by course experts and learners respectively. 
The personalised learning path is generated through the different stages of genetic algorithm. These different stages include; definition of chromosome strings, defining the initial population, selecting the fitness function, reproduction operation, crossover operation and the mutation operation which are described as follows:

Genetic algorithms (GAs) are general purpose search algorithms which use principles inspired by natural genetic populations to evolve solutions to problems. The basic idea is to maintain a population of chromosomes, which represent candidate solutions to the concrete problem that evolves over time through a process of competition and controlled variation. Each chromosome in the population has an associated fitness to determine which chromosomes are used to form new ones in the competition process, which is called selection. The new ones are created using genetic operators such as crossover and mutation [17]. In this research, genetic algorithm is used because several solutions are generated, out of which the best solution is chosen as the optimal learning path in order to get the best learners' performance. The genetic algorithm-based personalised e-learning system consists of the following steps:

\section{START \\ Gene variable: Difficulty level, degree of relationship \\ Initialise learning materials \\ Initialise course concepts \\ Generate random population set \\ FOR EACH course concept \\ Select corresponding Difficulty level \\ Select Degree of relationship \\ Combine both to form Chromosome \\ CONTINUE \\ Compute Fitness Function \\ REPEAT \\ Evaluate Fitness for Chromosome \\ FOR $i=1$ TO 6 \\ Get best learning path \\ Select two best learning path \\ Swap Gene to generate another two learning path \\ Perform CROSSOVER Operation \\ CONTINUE \\ Re-compute Fitness Values \\ Perform MUTATION operation for highest \\ value \\ IF Fitness Value > CROSSOVER Operation Optimal learning path \\ ELSE \\ Learning path with highest Fitness value STOP \\ UNTIL highest Fitness value}

Adesuyi et al. [18] model is adapted for estimating the student learning performance. Let $\mathrm{T}$ denotes the time given to go through a course concept, $\mathrm{t}$ denotes the time given to answer set of questions on a course concept, A denotes the exact time when resuming to go through a course concept, $\mathrm{Q}$ denotes the exact time when resuming for a course concept assessment, F denotes the exact time after finishing a course concept assessment, Y denotes the exact time spent by a student to go through a course concept and $\mathrm{Z}$ denotes the exact time spent by a student for course concept assessment. Then,

$$
\begin{aligned}
& Y=\frac{Q-A}{T} \\
& Z=\frac{P-Q}{t}
\end{aligned}
$$

Let $f(\phi)$ and $\Theta$ be a time status function and overall time status respectively such that;

$$
f(\phi)=\left\{\begin{array}{l}
\text { false }, Y, Z>1 \\
\text { true }, Y, Z \leq 1
\end{array}\right.
$$

and

$$
\Theta=f(Y) \wedge f(Z)
$$

Let $\mathrm{X}$ represent a single student, $\mathrm{c}$ denotes a single course concept, $\mathrm{P}$ denotes the total number of questions in the pretest, $\mathrm{Ca}$ the student responses that match the concept, Wa the student responses that do not match the concept, and $\mathrm{V}$ represent performance estimate. Then,

$$
\mathrm{\gamma}=\mathrm{Ca} /(\mathrm{Ca}+\mathrm{Wa})
$$

The student Learning performance category, L is expressed as:

$$
L= \begin{cases}\text { Partially successful },(\mathrm{\gamma}<0.5) \wedge & (\Theta=\text { false } \vee \Theta=\text { true }) \\ \text { Moderately successful, } & (\mathrm{\gamma}>0.5) \wedge(\Theta=\text { false }) \\ \text { Highly successful, } & (\mathrm{\gamma}>0.5) \wedge(\Theta=\text { true })\end{cases}
$$

\section{System Flowchart}

The Fig. 2 gives a detailed step by step way of realising the personalised e-learning system. Its different components include: the login, course concept materials, pretest and performance evaluation. When a user login to the system, the system verifies if the user is an instructor or a learner. If the user is an instructor which is also known as course concept expert, the instructor is allowed to prepare the learning material's course concepts, questionnaires and testing items. If the user is a learner, he is allowed to supply his profile Information. Thereafter, the learner is allowed to select the tasks to be performed such as course concepts to study and the need to respond to questions. The score of learner's learning performance in course concepts is displayed. 


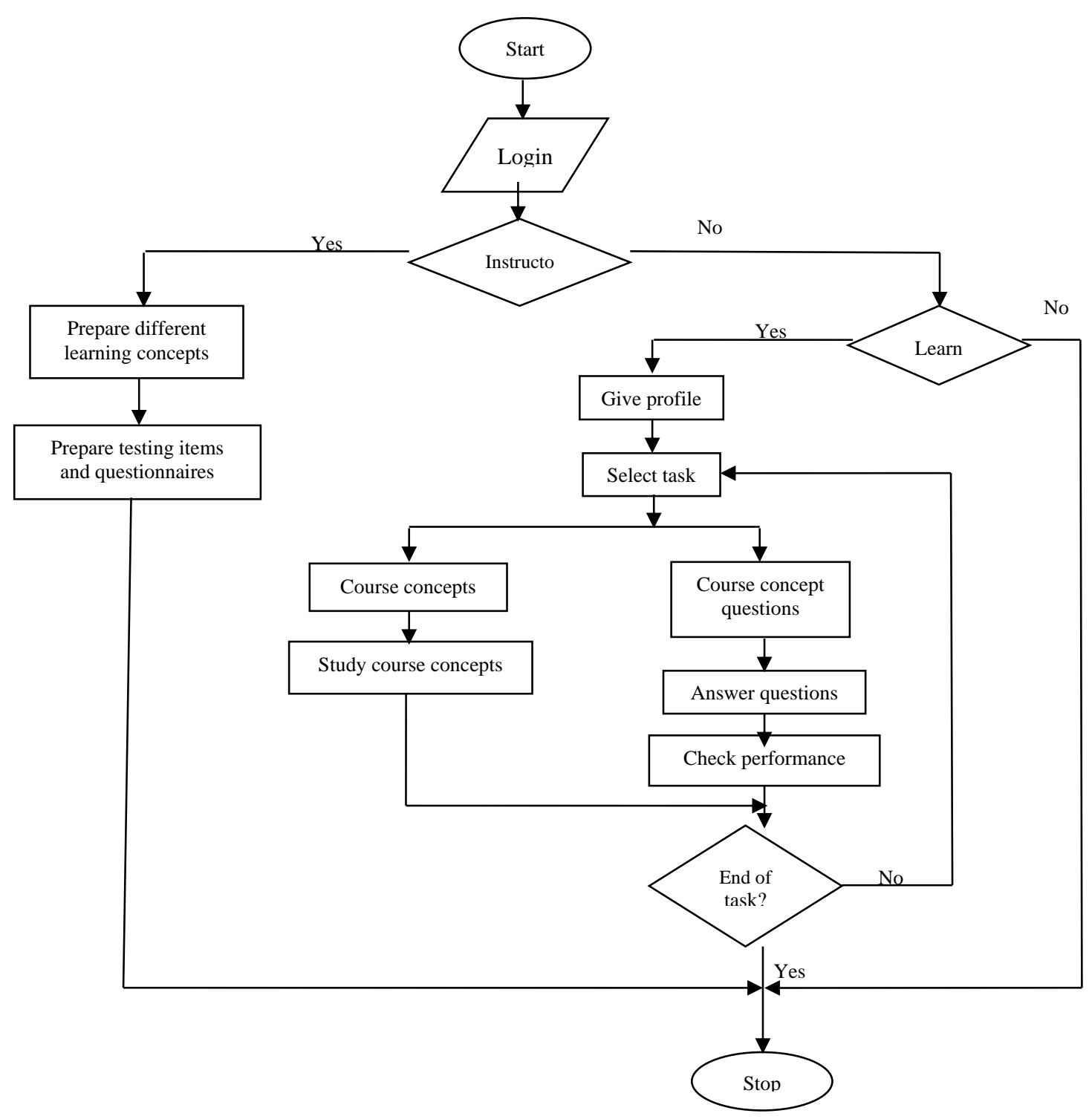

Fig.2. System Flowchart

\section{RESUlTS AND DISCUSSION}

The section discusses the results of using genetic algorithm in generating optimal learning path and the outcome of the assessment carried out on students based on the course concepts.

\section{A. Optimal Learning Path}

Table 1 shows the result of the difficulty level for the course concepts is based on the collaborative responses of the experts and learners' opinions from the questionnaires. Table 2 shows the result of the degree of relationship between course concepts. The Tables 1 and 2 are used as inputs into the genetic algorithm to generate the optimal learning path as depicted in Table 3.

Table 1 . The difficulty level for the course concepts was computed.

\begin{tabular}{|c|c|c|c|c|c|}
\hline & Learners & Experts & $\mathrm{w} * \mathrm{~b}_{\mathrm{j}}$ (initial) & $(1-\mathrm{w}) * \mathrm{~b}_{\mathrm{j}}($ response $)$ & $\begin{array}{c}\mathrm{w} * \mathrm{~b}_{\mathrm{j}}(\mathrm{initial})+(1-\mathrm{w}) * \\
\mathrm{~b}_{\mathrm{j}}(\text { response })\end{array}$ \\
\hline $\mathrm{C}_{1}$ & 1.73 & 1.88 & 0.0376 & 1.6954 & 1.7330 \\
\hline $\mathrm{C}_{2}$ & 1.13 & 1.46 & 0.0292 & 1.1074 & 1.1366 \\
\hline $\mathrm{C}_{3}$ & 1.63 & 1.66 & 0.0332 & 1.5974 & 1.6306 \\
\hline $\mathrm{C}_{4}$ & 1.33 & 1.66 & 0.0332 & 1.3034 & 1.1956 \\
\hline $\mathrm{C}_{5}$ & 1.19 & 1.46 & 0.0292 & 1.1662 & 1.1954 \\
\hline
\end{tabular}


Table 2. The degree of relationship between course concepts

\begin{tabular}{|c|c|c|c|c|c|}
\hline $\mathrm{r}_{\mathrm{i}, \mathrm{j}}$ & $\mathrm{C}_{1}$ & $\mathrm{C}_{2}$ & $\mathrm{C}_{3}$ & $\mathrm{C}_{4}$ & $\mathrm{C}_{5}$ \\
\hline $\mathrm{C}_{1}$ & 1 & 0.3866 & 0.4118 & 0.2000 & 0.1034 \\
\hline $\mathrm{C}_{2}$ & 0.3866 & 1 & 0.2488 & 0.0134 & 0.0974 \\
\hline $\mathrm{C}_{3}$ & 0.4118 & 0.2488 & 1 & 0.0459 & 0.0009 \\
\hline $\mathrm{C}_{4}$ & 0.2000 & 0.0134 & 0.0459 & 1 & 0.0601 \\
\hline $\mathrm{C}_{5}$ & 0.1034 & 0.0975 & 0.0009 & 0.0601 & 1 \\
\hline
\end{tabular}

Table 3. Optimal Learning Path Generated

\begin{tabular}{|l|l|l|l|}
\hline \multicolumn{2}{|l|}{ Learning Path } & Difficulty Level & $\begin{array}{l}\text { Concept relationship degree between } \\
\text { two successive concepts }\end{array}$ \\
\hline $\mathrm{C}_{1}$ & Introduction to computer networks & 1.7 & - \\
\hline $\mathrm{C}_{3}$ & Transmission media & 1.6 & 0.4118 \\
\hline $\mathrm{C}_{2}$ & Networks physical topology & 1.1 & 0.2488 \\
\hline $\mathrm{C}_{4}$ & OSI Reference model & 1.3 & 0.0134 \\
\hline $\mathrm{C}_{5}$ & Switching & 1.2 & 0.0601 \\
\hline
\end{tabular}

\section{B. Students' Learning Performance}

The learning material that was used for the purpose of this research work is Computer Network which involved five basic course concepts. The course concepts are synchronized with learning duration (T) and assessment duration ( $\mathrm{t}$ ) as shown in Table 4. The students' learning performance was determined by conducting summative assessment on nineteen (19) students from 400 level of Achievers University Owo, Ondo State and the results of the learning outcome of concepts $\left(\mathrm{C}_{1}\right.$ and $\left.\mathrm{C}_{5}\right)$ are depicted in Tables 5 and 6 respectively showing the learning understanding levels of the learners.

Table 4. Course concepts with the learning duration $(\mathrm{T})$ and assessment duration $(\mathrm{t})$

\begin{tabular}{|l|l|l|l|}
\hline \multicolumn{2}{|c|}{$C_{i}$} & \multicolumn{1}{c|}{$\mathrm{T}$} & \multicolumn{1}{c|}{} \\
\hline$C_{1}$ & Introduction to computer networks & 60 minutes & 10 minutes \\
\hline$C_{2}$ & Networks physical topology & 90 minutes & 12 minutes \\
\hline$C_{3}$ & Transmission media & 90 minutes & 15 minutes \\
\hline$C_{4}$ & The OSI reference model & 120 minutes & 15 minutes \\
\hline$C_{5}$ & Switching & 120 minutes & 15 minutes \\
\hline
\end{tabular}

Table 5. The learning category of learners in introduction to computer networks $(\mathrm{C} 1=$ Concept 1$)$

\begin{tabular}{|c|c|c|c|c|c|c|c|c|c|}
\hline $\mathrm{x}$ & $\mathrm{C}_{1}$ & $\mathrm{Y}$ (mins) & $\begin{array}{l}\mathrm{Z}(\mathrm{mins} \\
)\end{array}$ & $\mathrm{P}$ & $\mathrm{V}$ & $\mathrm{f}(\mathrm{Y})$ & $\mathrm{f}(\mathrm{Z})$ & $\Theta$ & $\mathrm{L}$ \\
\hline$x_{1}$ & \multirow{10}{*}{$\begin{array}{l}\text { Introduction } \\
\text { to } \\
\text { computer } \\
\text { networks }\end{array}$} & 60 & 10 & 10 & $\mathrm{C}_{\mathrm{a}}=7, \mathrm{~W}_{\mathrm{a}}=3$ & True & True & True & $\begin{array}{l}\text { Highly } \\
\text { successful }\end{array}$ \\
\hline$x_{2}$ & & 58 & 11 & 10 & $\mathrm{C}_{\mathrm{a}}=7, \mathrm{~W}_{\mathrm{a}}=3$ & True & False & False & $\begin{array}{l}\text { Moderately } \\
\text { successful }\end{array}$ \\
\hline$x_{3}$ & & 55 & 8 & 10 & $\mathrm{C}_{\mathrm{a}}=9, \mathrm{~W}_{\mathrm{a}}=1$ & True & True & True & $\begin{array}{l}\text { Highly } \\
\text { successful }\end{array}$ \\
\hline$x_{4}$ & & 62 & 12 & 10 & $\mathrm{C}_{\mathrm{a}}=7, \mathrm{~W}_{\mathrm{a}}=3$ & False & False & False & $\begin{array}{l}\text { Moderately } \\
\text { successful }\end{array}$ \\
\hline$x_{5}$ & & 52 & 9 & 10 & $\mathrm{C}_{\mathrm{a}}=8, \mathrm{~W}_{\mathrm{a}}=2$ & True & True & True & $\begin{array}{l}\text { Highly } \\
\text { successful }\end{array}$ \\
\hline$x_{6}$ & & 60 & 11 & 10 & $\mathrm{C}_{\mathrm{a}}=4, \mathrm{~W}_{\mathrm{a}}=6$ & False & False & False & $\begin{array}{l}\text { Partially } \\
\text { successful }\end{array}$ \\
\hline$x_{7}$ & & 58 & 10 & 10 & $\mathrm{C}_{\mathrm{a}}=8, \mathrm{~W}_{\mathrm{a}}=2$ & True & True & True & $\begin{array}{l}\text { Highly } \\
\text { successful }\end{array}$ \\
\hline$x_{8}$ & & 60 & 9 & 10 & $\mathrm{C}_{\mathrm{a}}=9, \mathrm{~W}_{\mathrm{a}}=1$ & True & True & True & $\begin{array}{l}\text { Highly } \\
\text { successful }\end{array}$ \\
\hline$x_{9}$ & & 58 & 7 & 10 & $\mathrm{C}_{\mathrm{a}}=7, \mathrm{~W}_{\mathrm{a}}=3$ & True & True & True & $\begin{array}{l}\text { Highly } \\
\text { successful }\end{array}$ \\
\hline$x_{10}$ & & 60 & 13 & 10 & $\mathrm{C}_{\mathrm{a}}=7, \mathrm{~W}_{\mathrm{a}}=3$ & True & False & False & $\begin{array}{l}\text { Moderately } \\
\text { successful }\end{array}$ \\
\hline
\end{tabular}




\begin{tabular}{|c|c|c|c|c|c|c|c|c|}
\hline$x_{11}$ & 60 & 9 & 10 & $\mathrm{C}_{\mathrm{a}}=7, \mathrm{~W}_{\mathrm{a}}=3$ & True & True & True & $\begin{array}{l}\text { Highly } \\
\text { successful }\end{array}$ \\
\hline$x_{12}$ & 59 & 11 & 10 & $\mathrm{C}_{\mathrm{a}}=7, \mathrm{~W}_{\mathrm{a}}=3$ & True & False & False & $\begin{array}{l}\text { Moderately } \\
\text { successful }\end{array}$ \\
\hline$x_{13}$ & 60 & 13 & 10 & $\mathrm{C}_{\mathrm{a}}=7, \mathrm{~W}_{\mathrm{a}}=3$ & True & False & False & $\begin{array}{l}\text { Moderately } \\
\text { successful }\end{array}$ \\
\hline$x_{14}$ & 60 & 10 & 10 & $\mathrm{C}_{\mathrm{a}}=8, \mathrm{~W}_{\mathrm{a}}=2$ & True & True & True & $\begin{array}{l}\text { Highly } \\
\text { successful }\end{array}$ \\
\hline$x_{15}$ & 58 & 9 & 10 & $\mathrm{C}_{\mathrm{a}}=8, \mathrm{~W}_{\mathrm{a}}=2$ & True & True & True & $\begin{array}{l}\text { Highly } \\
\text { successful }\end{array}$ \\
\hline$x_{16}$ & 62 & 13 & 10 & $\mathrm{C}_{\mathrm{a}}=7, \mathrm{~W}_{\mathrm{a}}=3$ & True & False & False & $\begin{array}{l}\text { Moderately } \\
\text { successful }\end{array}$ \\
\hline$x_{17}$ & 60 & 10 & 10 & $\mathrm{C}_{\mathrm{a}}=7, \mathrm{~W}_{\mathrm{a}}=3$ & True & True & True & $\begin{array}{l}\text { Highly } \\
\text { successful }\end{array}$ \\
\hline$x_{18}$ & 60 & 10 & 10 & $\mathrm{C}_{\mathrm{a}}=7, \mathrm{~W}_{\mathrm{a}}=3$ & True & True & True & $\begin{array}{l}\text { Highly } \\
\text { successful }\end{array}$ \\
\hline$x_{19}$ & 66 & 13 & 10 & $\mathrm{C}_{\mathrm{a}}=4, \mathrm{~W}_{\mathrm{a}}=6$ & False & False & False & $\begin{array}{l}\text { Partially } \\
\text { successful }\end{array}$ \\
\hline
\end{tabular}

Table 6. The learning category of learners in introduction to computer networks (C5 = Concept 5)

\begin{tabular}{|c|c|c|c|c|c|c|c|c|c|}
\hline $\mathrm{x}$ & $\mathrm{C}_{5}$ & $\mathrm{Y}(\mathrm{mins}$ & $\mathrm{Z}$ (mins) & $\mathrm{P}$ & $\mathrm{V}$ & $f(Y)$ & $f(Z)$ & $\Theta$ & $\mathrm{L}$ \\
\hline$x_{1}$ & Switching & 120 & 15 & 10 & $\mathrm{C}_{\mathrm{a}}=6, \mathrm{~W}_{\mathrm{a}}=4$ & True & True & True & $\begin{array}{l}\text { Highly } \\
\text { successful }\end{array}$ \\
\hline$x_{2}$ & & 120 & 15 & 10 & $\mathrm{C}_{\mathrm{a}}=6, \mathrm{~W}_{\mathrm{a}}=4$ & True & True & True & $\begin{array}{l}\text { Highly } \\
\text { successful }\end{array}$ \\
\hline$x_{3}$ & & 115 & 17 & 10 & $\mathrm{C}_{\mathrm{a}}=6, \mathrm{~W}_{\mathrm{a}}=4$ & True & False & False & $\begin{array}{l}\text { Moderately } \\
\text { successful }\end{array}$ \\
\hline$x_{4}$ & & 110 & 12 & 10 & $\mathrm{C}_{\mathrm{a}}=8, \mathrm{~W}_{\mathrm{a}}=2$ & True & True & True & $\begin{array}{l}\text { Highly } \\
\text { successful }\end{array}$ \\
\hline$x_{5}$ & & 100 & 12 & 10 & $\mathrm{C}_{\mathrm{a}}=9, \mathrm{~W}_{\mathrm{a}}=1$ & True & True & True & $\begin{array}{l}\text { Highly } \\
\text { successful }\end{array}$ \\
\hline$x_{6}$ & & 104 & 12 & 10 & $\mathrm{C}_{\mathrm{a}}=9, \mathrm{~W}_{\mathrm{a}}=1$ & True & True & True & $\begin{array}{l}\text { Highly } \\
\text { successful }\end{array}$ \\
\hline$x_{7}$ & & 120 & 14 & 10 & $\mathrm{C}_{\mathrm{a}}=7, \mathrm{~W}_{\mathrm{a}}=3$ & True & True & True & $\begin{array}{l}\text { Highly } \\
\text { successful }\end{array}$ \\
\hline$x_{8}$ & & 95 & 12 & 10 & $\mathrm{C}_{\mathrm{a}}=8, \mathrm{~W}_{\mathrm{a}}=2$ & True & True & True & $\begin{array}{l}\text { Highly } \\
\text { successful }\end{array}$ \\
\hline$x_{9}$ & & 118 & 14 & 10 & $\mathrm{C}_{\mathrm{a}}=7, \mathrm{~W}_{\mathrm{a}}=3$ & True & True & True & $\begin{array}{l}\text { Highly } \\
\text { successful }\end{array}$ \\
\hline$x_{10}$ & & 120 & 15 & 10 & $\mathrm{C}_{\mathrm{a}}=8, \mathrm{~W}_{\mathrm{a}}=2$ & True & True & True & $\begin{array}{l}\text { Highly } \\
\text { successful }\end{array}$ \\
\hline$x_{11}$ & & 120 & 14 & 10 & $\mathrm{C}_{\mathrm{a}}=7, \mathrm{~W}_{\mathrm{a}}=3$ & True & True & True & $\begin{array}{l}\text { Highly } \\
\text { successful }\end{array}$ \\
\hline$x_{12}$ & & 120 & 19 & 10 & $\mathrm{C}_{\mathrm{a}}=6, \mathrm{~W}_{\mathrm{a}}=4$ & True & False & False & $\begin{array}{l}\text { Moderately } \\
\text { successful }\end{array}$ \\
\hline$x_{13}$ & & 120 & 17 & 10 & $\mathrm{C}_{\mathrm{a}}=5, \mathrm{~W}_{\mathrm{a}}=5$ & True & False & False & $\begin{array}{l}\text { Moderately } \\
\text { successful }\end{array}$ \\
\hline$x_{14}$ & & 120 & 15 & 10 & $\mathrm{C}_{\mathrm{a}}=6, \mathrm{~W}_{\mathrm{a}}=4$ & True & True & True & $\begin{array}{l}\text { Highly } \\
\text { successful }\end{array}$ \\
\hline$x_{15}$ & & 120 & 118 & 10 & $\mathrm{C}_{\mathrm{a}}=5, \mathrm{~W}_{\mathrm{a}}=5$ & True & False & False & $\begin{array}{l}\text { Moderately } \\
\text { successful }\end{array}$ \\
\hline$x_{16}$ & & 115 & 15 & 10 & $\mathrm{C}_{\mathrm{a}}=6, \mathrm{~W}_{\mathrm{a}}=4$ & True & True & True & $\begin{array}{l}\text { Highly } \\
\text { successful }\end{array}$ \\
\hline$x_{17}$ & & 120 & 13 & 10 & $\mathrm{C}_{\mathrm{a}}=7, \mathrm{~W}_{\mathrm{a}}=3$ & True & True & True & $\begin{array}{l}\text { Highly } \\
\text { successful }\end{array}$ \\
\hline$x_{18}$ & & 120 & 19 & 10 & $\mathrm{C}_{\mathrm{a}}=6, \mathrm{~W}_{\mathrm{a}}=4$ & True & False & False & $\begin{array}{l}\text { Moderately } \\
\text { successful }\end{array}$ \\
\hline$x_{19}$ & & 116 & 15 & 10 & $\mathrm{C}_{\mathrm{a}}=4, \mathrm{~W}_{\mathrm{a}}=6$ & True & True & True & $\begin{array}{l}\text { Partially } \\
\text { successful }\end{array}$ \\
\hline
\end{tabular}


Figs. 3 and 4 indicate the classification of the nineteen (19) learners to different learning performance categories based on the level of learners' understanding of the concepts $\left(\mathrm{C}_{1}\right.$ and $\left.\mathrm{C}_{5}\right)$. It is observed that two (2) learners belong to the partially successful category, six (6) learners belong to the moderately successful and eleven
(11) learners belong to the highly successful category in concept $\mathrm{C}_{1}$. Furthermore, one (1) learner belong to the partially successful category, five (5) learners belong to the moderately successful category and thirteen (13) learners belong to the highly successful category $C_{5}$.

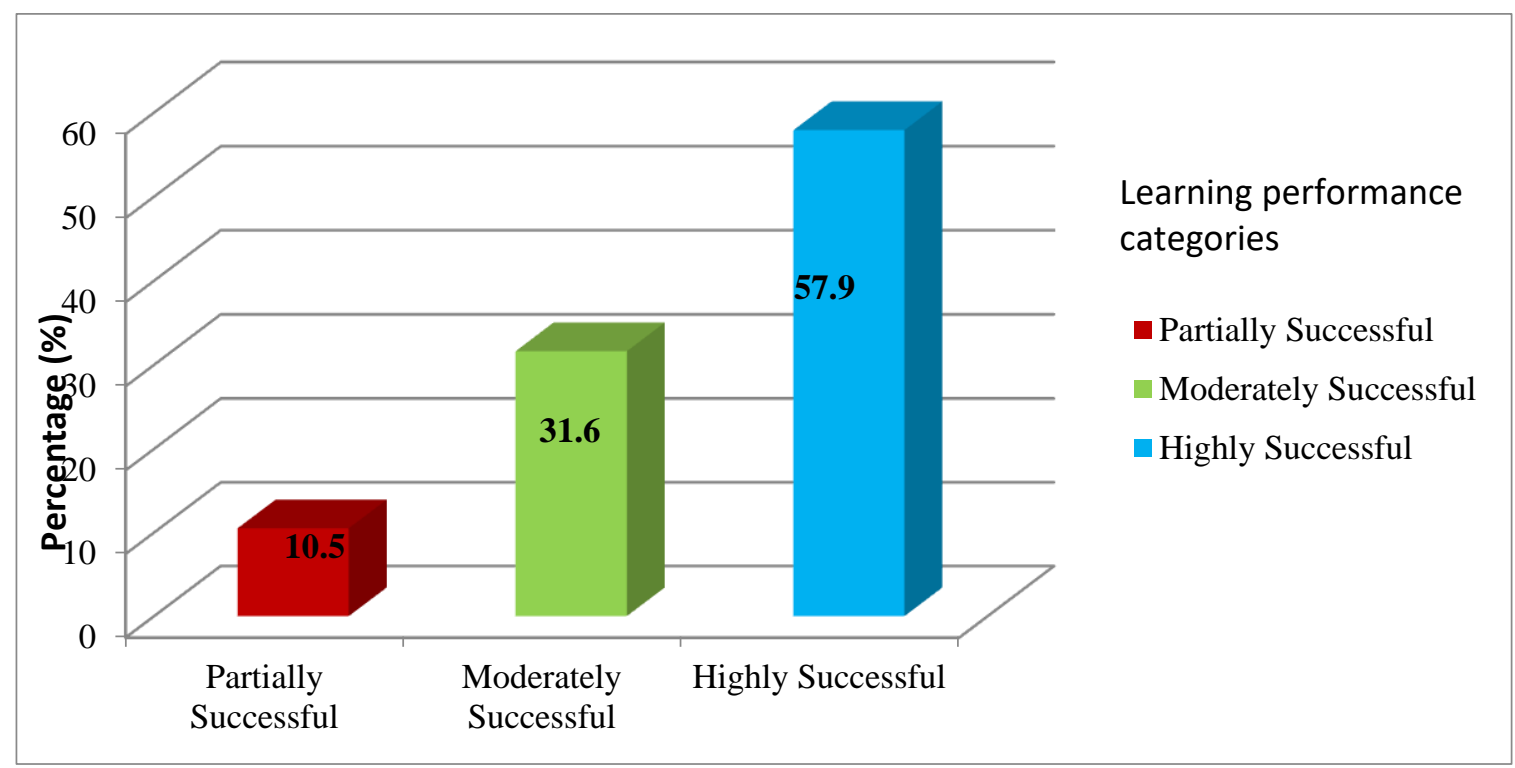

Fig.3. Student Learning Performance categories in Course Concept 1

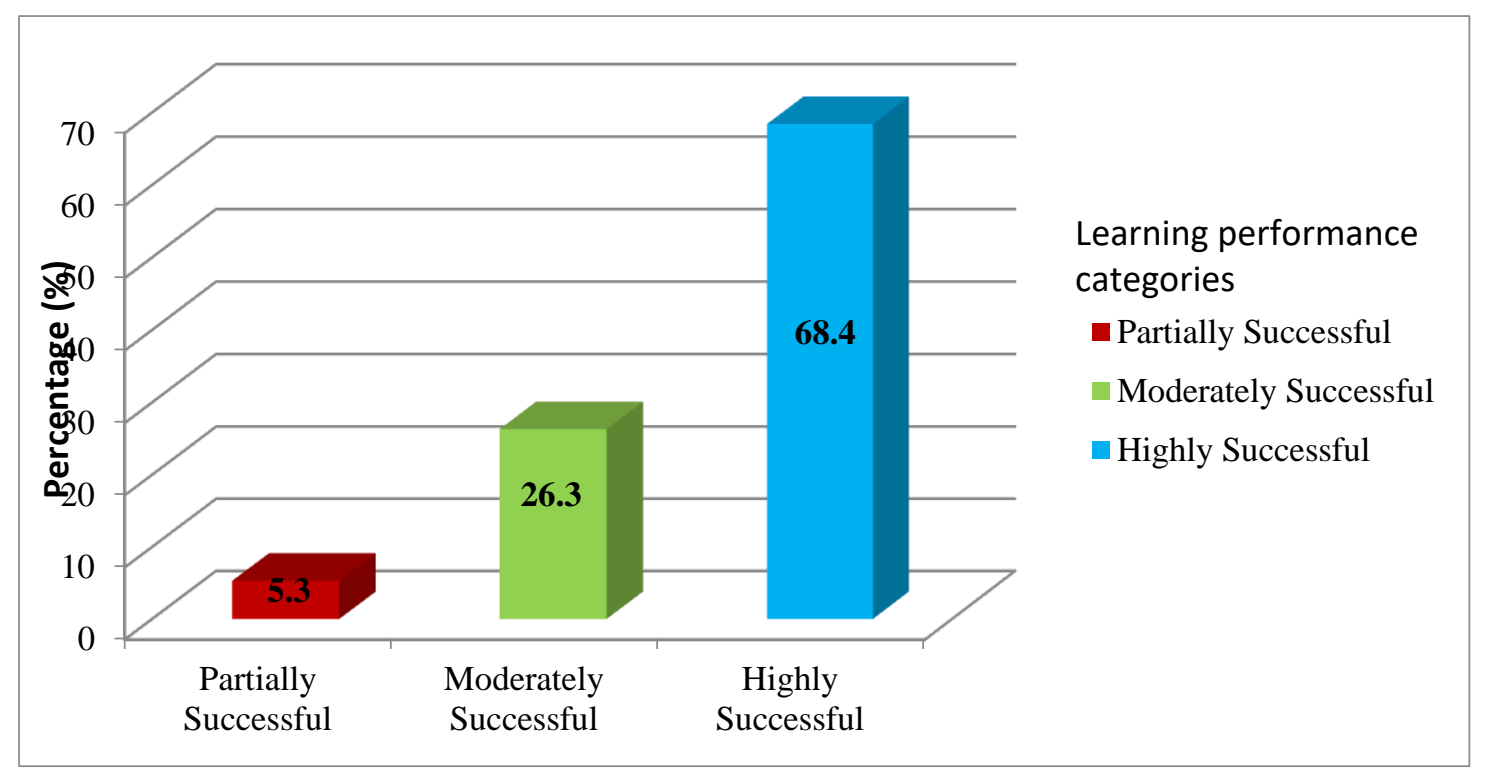

Fig.4. Student Learning Performance categories in Course Concept 5

\section{CONCLUSION}

The concept of personalised e-learning is currently a research focus in the fields of education and psychology that has received great attention in order to deliver learning in a manner that attracts learners' requirements such as learners' interest, motivation and background knowledge. In this research work, a genetic algorithm- based curriculum sequencing model in personalised elearning environment was presented. The research adopted genetic algorithm to generate the optimal learning path for the learners by considering both the difficulty level and degree of relationship between course concepts. Based on the performance assessment, the results of the learners' learning outcome of the course concepts showed the significance of the curriculum sequencing in personalised e-learning system. 


\section{REFERENCES}

[1] S. T. Njenga, R. O. Oboko, E. I. Omwenga and E. M. Maina, "Use of Intelligent Agents in Collaborative MLearning: Case of Facilitating Group Learner Interactions," I.J. Modern Education and Computer Science, vol. 9, no 10, pp. 18-28, 2017, DOI:10.5815/ijmecs.2017.10.03.

[2] M. N. Mutua, "A Correlation Study between Learning Styles and Academic Achievement Among Secondary School Students in Kenya," M.Ed thesis submitted to the Department of Psychology, University of Nairobi, Kenya, 2015

[3] A. I Jony, S Rahman and Y. M. Islam, "ICT in Higher Education: Wiki-based "ICflection to Promote Deeper Thinking Levels," I.J. Modern Education and Computer Science, vol. 9, no. 4, pp.43-49, 2017, DOI: 10.5815/ijmecs.2017.04.05.

[4] A. W. Mary, "Innovate to Educate. System Redesign for Personalised Learning," A Report from the 2010 Symposium, Washington DC, USA.

[5] C. Latha and E. Kirubakaran, "Personalised Learning Path Delivery in Web based Educational Systems using a Graph Theory based Approach," Journal of American Science, vol. 9, no. 12, pp. 57-67, 2013.

[6] C. M. Chen, M. H. Chang, C. Y. Liu, and W. C. Chiu, "Personalised Learning Path Generation Based on RealCoded Genetic Algorithm for Web-based Instruction,". In Proceedings of the 16th International Conference of Information Management (ICIM), pp. 56, 2005.

[7] C. M. Hong, C. Chih-Ming and C. Mei-Hui, "Personalised Learning Path Generation Approach for Web-based Learning," $4^{\text {th }}$ World Scientific and Engineering Academy and Society International Conference on E-Activities, Miami, Florida, USA, pp.62-68, 2005.

[8] I. Khaled, "Information and Communication Technologies within Human Resource Development, A Case Study on the Swedish Banking Industry", M Sc. thesis submitted to the Department of Business Administration, Technology and Social Sciences, Luleå University of Technology. 2011.

[9] M. J. Huang, H. S. Huang and M. Y. Chen, "Constructing a Personalised elearning System based on Genetic Algorithm and Case-based Reasoning Approach, Expert Systems with Applications, 33, 551-564, 2007.

[10] O. Oduwobi, "Development of a Personalised Electronic Learning Material Recommender System," unpublished M.tech thesis submitted to the Department of Computer Science, Federal University of Technology, Akure. Nigeria, 2011.

[11] S. Muthulakshmi and G. V Uma, "E-guru - Design and Development of Ontology-based E-learning System for Sports Domain," European Journal of Scientific Research, vol.53, no. 2 pp. 298-305, 2011.

[12] O. C. Agbonifo, O. S. Adewale and B. K Alese, (2013), "Design of a Neurofuzzy-based Model for Active and Collaborative Online Learning," International Journal of Education and Research, vol. 1, no. 10, pp. 1-22, 2013.
[13] A. A. Elusoji,"Development of Web-based Adaptive Learning Resources Sequencing Model," unpublished $\mathrm{PhD}$ thesis submitted to the Department of Computer Science, Federal University of Technology, Akure, Nigeria. 2015.

[14] L. Pasquale, G. Marco and S. Giovanni, "Content-based Recommender Systems: State of the Art and Trends," Recommender Systems Handbook, Chapter 3, pp. 73-105, 2011.

[15] N. C. John and O. Joseph, "A Web Content-Based Recommender System to Promote Automatic Discovery of Learning Content for High School Students," M Sc. thesis submitted to the School of Computing and Informatics, University of Nairobi, Kenya, 2014.

[16] H. M. Lee, M. C. Chih and C. Ya-Hui, "Personalised elearning system using Item Response Theory," Computers \& Education, vol. 44, no. 3, pp. 237-255, 2005.

[17] F. Herrera, M. Lozano and J. L. Verdegay, "Operators and Tools for Behavioural Analysis," Artificial Intelligence Review 12. pp. 265-319, 1998.

[18] A. T. Adesuyi, O. S. Adewale and A. F. Thompson, "Ontology-Based Personalisation System for E-Learning," International Journal of Computer Science, Engineering \& Technology, vol. 1, no. 1, pp. 1-11, 2014.

\section{Authors' Profiles}

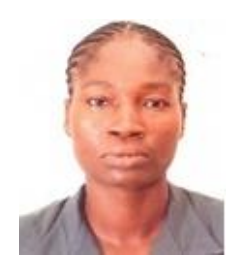

Oluwatoyin C. Agbonifo obtained her B.Sc. degree in Computer Science from the University of Ibadan, Ibadan, Nigeria in 1995. She also received her M.Tech. and $\mathrm{PhD}$ degrees in Computer Science from the Federal University of Technology, Akure, Nigeria in 2005 and 2012 respectively. She has been a lecturer in the Department of Computer Science. Federal University of Technology, Akure since 2006. She has authored/co-authored a number of articles at both local and international refereed journals and conference proceedings. She is a regular reviewer in local as well as international scientific/academic journals. Dr.(Mrs.) Agbonifo is a member of the NCS, CPN, IEEE, AACE and OWSD. Her research interest areas include: Personalised and Adaptive Ubiquitous learning Systems, Digital Game-Based Learning Systems, Software Engineering and Artificial Intelligence.

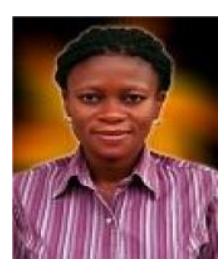

Olanrewaju A. Obolo obtained a Bachelor of Technology (B.Tech) Degree in Computer Science from the Federal University of Technology, Akure, Ondo State, Nigeria, in 2010. She also obtained her Masters of Technology (M.Tech) Degree in Computer Science from the Federal University of Technology, Akure, Ondo State, Nigeria, in 2016.

How to cite this paper: Oluwatoyin C. Agbonifo, Olanrewaju A. Obolo, "Genetic Algorithm-based Curriculum Sequencing Model For Personalised E-Learning System", International Journal of Modern Education and Computer Science(IJMECS), Vol.10, No.5, pp. 27-35, 2018.DOI: 10.5815/ijmecs.2018.05.04 